\title{
Article \\ Surface Passivation Using N-Type Organic Semiconductor by One-Step Method in Two-Dimensional Perovskite Solar Cells
}

\author{
Helong Wang ${ }^{1,2}$, Guanchen Liu ${ }^{3}$, Chongyang $\mathrm{Xu}^{4}$, Fanming Zeng ${ }^{1, *}$, Xiaoyin Xie ${ }^{3,5, *(1)}$ and Sheng Wu ${ }^{4, *}$ \\ 1 School of Materials Science and Engineering, Changchun University of Science and Technology, \\ Changchun 130022, China; whljls@126.com \\ 2 School of Mechanical Engineering, Jilin Railway Technology College, Jilin 132200, China \\ 3 School of Chemistry and Chemical Technology, Hubei Polytechnic University, Huangshi 435003, China; \\ liuguanchen1123@163.com \\ 4 Yantai Research Institute and Graduate School of HEU, Harbin Engineering University, Harbin 150001, China; \\ xcy666@163.com \\ 5 Department of Physics, Gachon University, Gyeonggi 13120, Korea \\ * Correspondence: zengfm@126.com (F.Z.); xyxie@hbpu.edu.cn (X.X.); wusheng@hrbeu.edu.cn (S.W.)
}

Citation: Wang, H.; Liu, G.; Xu, C.; Zeng, F.; Xie, X.; Wu, S. Surface Passivation Using N-Type Organic Semiconductor by One-Step Method in Two-Dimensional Perovskite Solar Cells. Crystals 2021, 11, 933. https://doi.org/10.3390/cryst11080933

Academic Editors: Dmitry Medvedev, Wei Liu, Xin Wu and Haoran Lin

Received: 5 July 2021

Accepted: 9 August 2021

Published: 12 August 2021

Publisher's Note: MDPI stays neutral with regard to jurisdictional claims in published maps and institutional affiliations.

Copyright: () 2021 by the authors. Licensee MDPI, Basel, Switzerland. This article is an open access article distributed under the terms and conditions of the Creative Commons Attribution (CC BY) license (https:// creativecommons.org/licenses/by/ $4.0 /)$.

\begin{abstract}
Surface passivation, which has been intensively studied recently, is essential for the perovskite solar cells (PSCs), due to the intrinsic defects in perovskite crystal. A series of chemical or physical methods have been published for passivating the defects of perovskites, which effectively suppressed the charge recombination and enhanced the photovoltaic performance. In this study, the n-type semiconductor of [6,6]-phenyl- $\mathrm{C}_{61}$-butyric acid methyl ester (PCBM) is dissolved in chlorobenzene $(\mathrm{CB})$ for the surface passivation during the spin-coating process for depositing the two-dimensional (2D) perovskite film. This approach simplifies the fabrication process of 2D PSCs and benefits the film quality. As a result, the defects of perovskite film are effectively passivated by this method. A better perovskite/PCBM heterojunction is generated, exhibiting an increased film coverage and improved film morphology of PCBM. It is found that this technology results in an improved electron transporting performance as well as suppressed charge recombination for electron transport layer. As a result, PSCs based on the one-step formed perovskite/PCBM heterojunctions exhibit the optimized power conversion efficiency of $15.69 \%$ which is about $37 \%$ higher than that of regular perovskite devices. The device environmental stability is also enhanced due to the quality improved electron transport layer.
\end{abstract}

Keywords: perovskite solar cells; electron transport layer; 2D perovskite; anti-solvent

\section{Introduction}

Organo-inorganic hybrid perovskite solar cells (PSCs) have grabbed considerable attention due to their excellent characters, such as strong light absorption, long carrier diffusion length, high charge carrier mobility, and cost-effective production [1-5]. Within one decade of development, the power conversion efficiency (PCE) of PSCs has been over $25 \%$ [6], reaching a comparable level to those of their commercialized counterparts, e.g., cadmium telluride (CdTe), and copper indium gallium selenide (CIGS) solar cells [7]. Moreover, because of the nature of their mechanical flexibility, PSCs are compatible with the continuous roll-to-roll production, a kind of batch production, exhibiting the potential for a wider range of practical application [8-12]. However, due to the ionic bond and crystal structure, perovskite devices suffer from the poor environmental stability and moisture resistance which could obviously accelerate the degradation rate of perovskites [13-17]. A lot of effort has been made to solve such defects, including element doping, solvent engineering, and interfacial modification [3,18-21]. These methods yield the perovskite film with a better quality by modifying the crystal structure, optimizing the crystal configuration, and improving the interfacial morphology, which means decreasing the defects 
and increasing the regularity. Many methods have been studied in three-dimensional PSCs, which are also meaningful for the two-dimensional (2D) PSCs [22-26]. Due to the special character of 2D perovskites, passivating the defects in 2D perovskite may be more significant. Generally, the 2D perovskites can be presented with the molecular formula of $\mathrm{A}_{2} \mathrm{~B}_{\mathrm{n}-1} \mathrm{M}_{\mathrm{n}} \mathrm{X}_{3 \mathrm{n}+1}$, where $\mathrm{M}$ stands for metal ion, e.g., $\mathrm{Pb}^{2+}$ or $\mathrm{Sn}^{2+}$, X presents halide ion, A stands for spacer cation, such as $\mathrm{CH}_{3}\left(\mathrm{CH}_{2}\right)_{3} \mathrm{NH}_{3}{ }^{+}\left(\mathrm{BA}^{+}\right)$or $\mathrm{C}_{6} \mathrm{H}_{5}\left(\mathrm{CH}_{2}\right)_{2} \mathrm{NH}_{3}{ }^{+}\left(\mathrm{PEA}^{+}\right)$, $\mathrm{B}$ is $\mathrm{CH}_{3} \mathrm{NH}_{3}{ }^{+}\left(\mathrm{MA}^{+}\right), \mathrm{HC}\left(\mathrm{NH}_{2}\right)_{2}{ }^{+}\left(\mathrm{FA}^{+}\right)$, or $\mathrm{Cs}^{+}$[27]. $\mathrm{N}$ stands for the number of metal halide monolayer sheets. When increasing the $\mathrm{n}$ value from 1 to $\infty$, the perovskite structure gradually turns from pure 2D phases into 3D perovskites [28]. The 2D perovskite sheets are surrounded with the organic spacers which are hydrophobic and could provide robust moisture resistance [29]. That is one of the crucial reasons why 2D perovskite devices usually exhibit excellent environmental stability. However, these spacer molecules can effectively suppress the charge transfer when $n$ values are low (i.e., $n<5$ ) [30]. In addition, it demanded more optimization for depositing the functional layer on top of the 2D perovskite due to its hydrophobic character. Therefore, 2D PSCs usually exhibit a lower PCE compared with their 3D counterparts.

Many efforts have been made to elevate photovoltaic performance of 2D perovskite devices, including optimizing crystal orientation and crystallographic texture of 2D perovskites [27,29]. H. Chen's group obtained the vertically orientated 2D perovskites with high crystal quality by adding an appropriate amount of $\mathrm{NH}_{4} \mathrm{SCN}$ into perovskite precursor as the additive, achieving a PCE of 11.01\% [31]. A. D. Mohite et al. obtained 2D light absorber with vertical orientation using a hot casting approach, yielding an optimized PCE of $12.5 \%$ with well suppressed photocurrent hysteresis [29]. Their developed 2D PSCs presented obviously enhanced environmental stability compared with the 3D counterparts. Compared with the research directions about developing the $2 \mathrm{D}$ perovskite crystal quality, optimizing the charge transport layers (CTLs), i.e., electron transport layer (ETLs) and hole transport layers (HTLs), seems less popular. However, in the field of 3D PSCs, developing the CTLs are quite meaningful for boosting the photovoltaic performance of devices, e.g., the open circuit voltage $\left(V_{o c}\right)$ and short circuit current $\left(J_{s c}\right)$ can be obviously improved by optimizing the ETLs [32-34]. C. Xu developed the ETL of 3D planar inverted PSC s by replacing conventional [6,6]-phenyl-C61-butyric acid methyl ester (PCBM) with the fullerene mixture of C60/C70 and achieved a PCE improved from 15.2 to 16.9\%[19]. J. Huang's group obtained the structural order of PCBM layer using the solvent annealing process and the PCE of perovskite sample was improved from 17.1 to $19.4 \%$ [33]. They argued that the quality improved ETL had a significant impact on the performance of PSCs and the $V_{o c}$ was effectively enhanced. Hence, developing the ETL is quite meaningful and necessary for improving the performance of 2D PSCs.

In this work, we report a facile approach to improve the photovoltaic performance and environmental stability of inverted 2D PSCs by passivating the 2D perovskite with the PCBM solution. Regularly, the PCBM is dissolved into chlorobenzene (CB) to make the PCBM solution which is dropped on the formed perovskite film to deposit the ETL. However, we applied the one-step method (OSM) by dropping the PCBM solution as the anti-solvent during spinning the perovskite. By this way, the defects of perovskite film were effectively passivated and a better film coverage of PCBM was obtained. As a result, the 2D perovskite devices based on one-step method (OSM) exhibit a PCE of $12.8 \%$, which is obviously elevated compared with that of control group $(8.0 \%)$. At the same time, the long-term stability is also evidently enhanced. These results provide more aspects about developing the performance of 2D PSCs.

\section{Materials and Methods}

\subsection{Chemicals and Reagents}

Butylamine hydroiodide (BAI) and lead iodide $\left(\mathrm{PbI}_{2}\right)$ were bought from Tokyo Chemical Industry Co., Ltd. (Tokyo, Japan). N,N-dimethylformamide (DMF) and CB were obtained from Sigma-Aldrich (Schnelldorf, Germany), while methylammonium io- 
dide (MAI) and 2,9-dimethyl-4,7-diphenyl-1,10-phenanthroline (BCP) were purchased from Xi'an Polymer Light Technology Corp (Xi'an, China). PCBM was purchased from Nano-C Inc. (Westwood, MA, USA), while poly(3,4-ethylenedioxythiophene) polystyrene sulfonate (PEDOT:PSS) (Clevious PVP AI 4083) was acquired from H.C. Starck company (Goslar, Germany). The Indium tin oxide (ITO) patterned glasses were bought from Ying Kou You Xuan Trade Co., Ltd. (Yingkou, China).

\subsection{Device Fabrication}

The ITO patterned glasses were cleaned with detergent, deionized water, and isopropanol (IPA), and each process was under the ultrasonic bath for $15 \mathrm{~min}$, which was followed by the ultraviolet-ozone treatment for $20 \mathrm{~min}$. PEDOT:PSS layer was spin-coated at $4000 \mathrm{rpm}$ for $30 \mathrm{~s}$ followed by a thermal annealing treatment at $140{ }^{\circ} \mathrm{C}$ for $15 \mathrm{~min}$. The precursor of $(\mathrm{BA})_{2}(\mathrm{MA})_{3} \mathrm{~Pb}_{4} \mathrm{I}_{13}$ was prepared by dissolving $\mathrm{BAI}(0.5 \mathrm{M}), \mathrm{PbI}_{2}(1.0 \mathrm{M})$, and MAI $(0.75 \mathrm{M})$ in anhydrous mixed solvents (DMF: DMSO $=4: 1, v: v)$, which were then stirred for $8 \mathrm{~h}$ at $70{ }^{\circ} \mathrm{C}$ followed by thermal annealing at $100{ }^{\circ} \mathrm{C}$ for $10 \mathrm{~min}$. The perovskite film was formed by spin-coating the precursor solution at $1000 \mathrm{rpm}$ for $6 \mathrm{~s}$ and then $6000 \mathrm{rpm}$ for $60 \mathrm{~s}$ with the precursor in a nitrogen-filled glove box. During the spin coating, the PCBM solution $(600 \mu \mathrm{L})$, which was prepared by dissolving PCBM $(10,20$, and $30 \mathrm{mg} \mathrm{mL}^{-1}$ ) in $\mathrm{CB}$, was quickly dropped onto the sample at a delay time of $8 \mathrm{~s}$. The samples were then thermally annealed on a hot plate at $100{ }^{\circ} \mathrm{C}$ for $20 \mathrm{~min}$. Finally, Ag electrode with thickness of $100 \mathrm{~nm}$ was thermally coated on top of solar cells (working area of $\left.0.1 \mathrm{~cm}^{2}\right)$ under high vacuum $\left(<6.0 \times 10^{-6}\right.$ Torr $)$.

\subsection{Characterization}

Top-view scanning electron microscopy (SEM) images were measured with a JSM$7500 \mathrm{~F}$ field-emission SE microscope (JOEL, Japan) at the acceleration voltage of $20 \mathrm{kV}$, while ultraviolet-visible (UV-vis) absorption spectra were checked with a UV-vis-near-infrared 3600 spectrometer (Shimadzu, Japan). The current density-voltage $(J-V)$ characteristics of the 2D PSCs were recorded under an irradiation intensity of $100 \mathrm{~mW} \mathrm{~cm}^{-2}$ (AM 1.5), while the electrochemical impedance spectroscopy (EIS) was measured using an electrochemical workstation (CH1622D Instruments, USA) under a bias voltage near the $V_{o c}$ of the devices in dark. The external quantum efficiency (EQE) of the PSCs was performed using a Solar Cell incident photon-to-current efficiency measurement system (Solar Cell Scan 100, Zolix, China).

\section{Results and Discussion}

To fabricate the inverted 2D PSCs, each functional layer was deposited in the stacking order of glass/ITO/PEDOT:PSS/perovskite/PCBM/BCP/Ag, as exhibited in Figure 1a. As shown in Figure 1b, the PSBM-assisted anti-solvent, which was prepared by dissolving PCBM powder into $C B$, was dropped on top of perovskite film during the spin-coating process to produce a perovskite/PCBM heterojunction. This approach integrated the two steps of casting anti-solvent and depositing ETL, which simplified the device fabrication process and yielded quality improved PCBM film. 


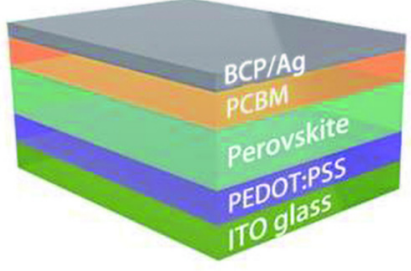

(a)

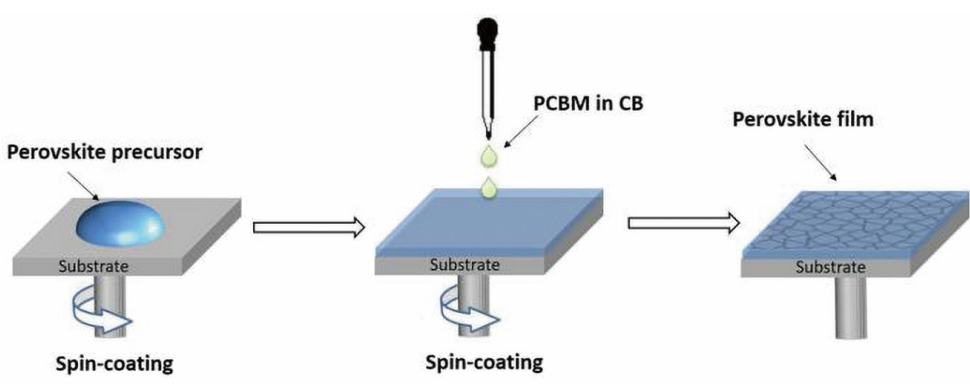

(b)

Figure 1. (a) Illustration of inverted-type 2D PSC with the configuration of glass/ITO/PEDOT:PSS/ perovskite/PCBM/BCP/Ag. (b) Schematic of perovskite deposition process using PCBM-assisted anti-solvent.

To estimate the influence caused by the one-step deposition method, J-V characteristics (reverse and forward scan) were measured. As shown in Figure 2a, applying the OSM resulted in an obviously improved photovoltaic performance, delivering a PCE of $12.8 \%$ along with $V_{o c}$ of $1.12 \mathrm{~V}, J_{s c}$ of $15.69 \mathrm{~mA} \mathrm{~cm}^{-2}$, and FF of 0.73 (reverse scan). As comparison, the PSC with PCBM deposited using regular method exhibited the PCE, $V_{o c}, J_{s c}$, and FF of $8.0 \%$, $1.06 \mathrm{~V}, 11.45 \mathrm{~mA} \mathrm{~cm}^{-2}$, and 0.66 , respectively, in reverse scanning mode. The passivated perovskite film may contribute to the improved PCE. Note that the experimental group demonstrated a PCE of $11.9 \%$ in forward scanning mode, delivering the hysteresis index of 0.06 which can be calculated by the equation of $\left(\mathrm{PCE}_{\text {reverse }}-\mathrm{PCE}_{\text {forward }}\right) / \mathrm{PCE}_{\text {reverse }}$ [24]. However, the control group presented a higher hysteresis index of 0.09 , suggesting that using the OSM is beneficial to suppress the hysteresis effect, which indicated the decreased defects. As exhibited in Figure 2c, the EQE spectra were recorded to compare the variation of photocurrents, in which the OSM based sample exhibited an obviously elevated photocurrent in almost the whole spectrum range compared with the control group. The integrated $J s c$ from EQE curves is $11.03 \mathrm{~mA} \mathrm{~cm}^{-2}$ for generally formed PCBM and $15.15 \mathrm{~mA} \mathrm{~cm}^{-2}$ for one-step formed PCBM, which agree with the data obtained in the J-V characteristics in Figure 2a. Furthermore, the stabilized photocurrent and PCE outputs of 2D PSCs using PCBM formed in different approaches were recorded. As shown in Figure 2c, the OSM based sample exhibited a stabilized photocurrent of $15.18 \mathrm{~mA} \mathrm{~cm}^{-2}$ and PCE of $12.3 \%$. This stabilized PCE is about $97 \%$ of its initial value obtained in J-V characteristics, which is slightly higher than that (96\%) of the control group, corresponding with the suppressed hysteresis [21].

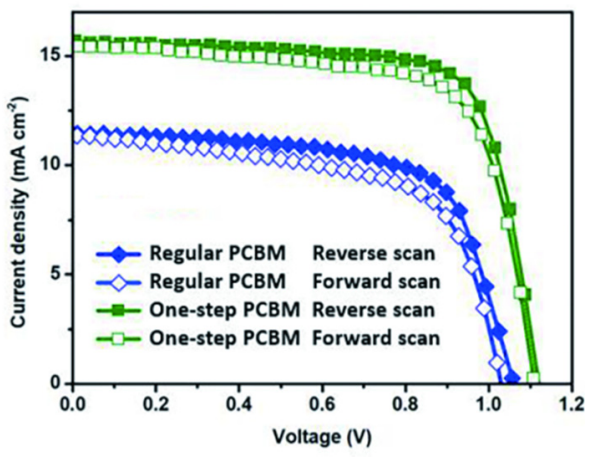

(a)

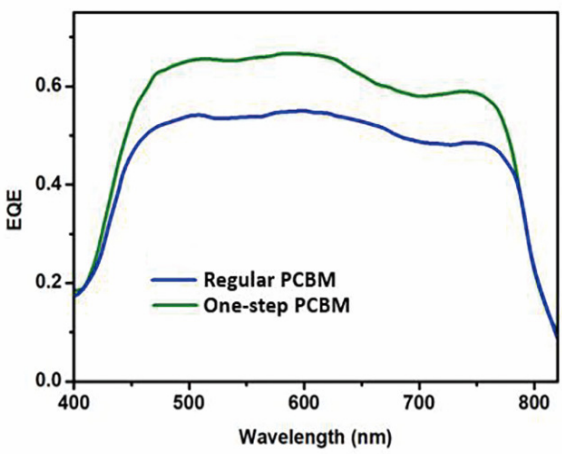

(b)

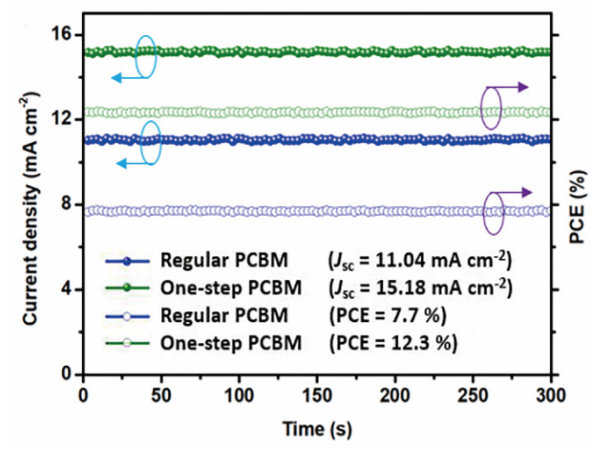

(c)

Figure 2. (a) J-V characteristics (reverse and forward scan), (b) EQE spectra, and (c) stabilized photocurrent as well as PCE outputs of 2D PSCs with PCBM formed with regular and one-step method. 
To figure out the mechanism of the improved photovoltaic performance caused by the one-step deposited PCBM, the top-view SEM images were measured. As demonstrated in Figure 3a, the PCBM formed in regular method presented some gaps among the clusters, showing a poor film coverage, which may be caused by the robust hydrophobic character of 2D perovskite [27]. These gaps increased the opportunity of charge recombination and brought negative effects to device performance. As a contrast, the PCBM deposited with OSM exhibited a denser film with no gaps, which ensured a better electron transporting process. We deduce that the dense PCBM cluster is caused by the quickly dropped solution which is evaporated in a short time.

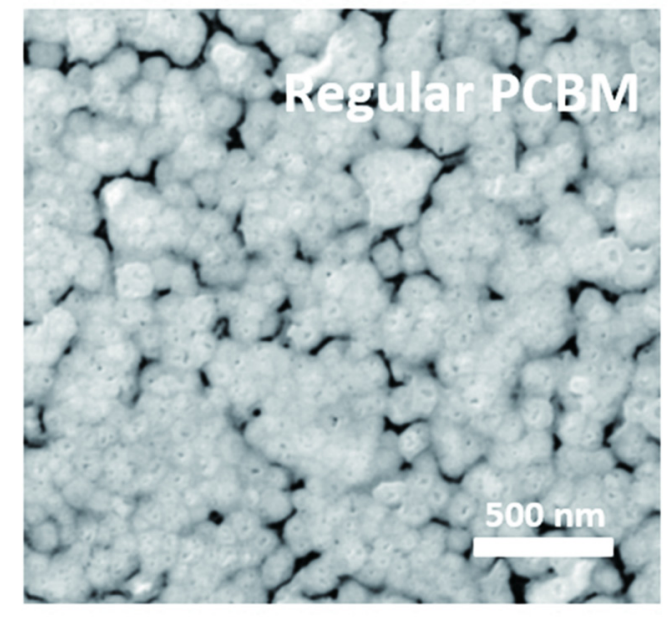

(a)

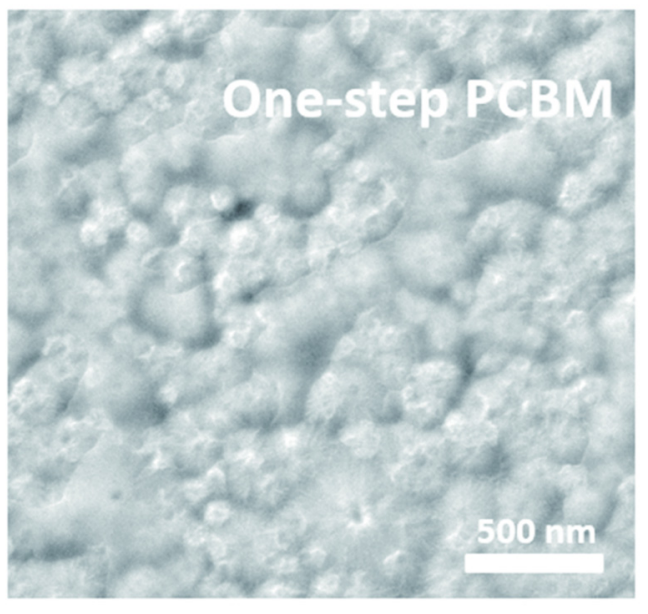

(b)

Figure 3. Top-view SEM images for $(\mathrm{BA})_{2}(\mathrm{MA})_{3} \mathrm{~Pb}_{4} \mathrm{I}_{13}$ deposited with (a) regular and (b) one-step method.

To further understand the variation about electrical performance affected by various film deposition methods, PL spectra were measured for the samples with configuration of perovskite, perovskite/PCBM (regular method), and perovskite/PCBM (one-step method). As shown in Figure $4 \mathrm{a}$, all the emission peaks were around $740 \mathrm{~nm}$ which agreed with previous reports. An obviously shrinking effect occurred after depositing the PCBM (regular method) on top of perovskite film, suggesting the excellent electron transporting performance. When depositing PCBM with OSM, the emission peak decreased further, delivering the value around 70\% of the PCBM sample (regular method). This decreased peak intensity may indicate that the OSM based PCBM exhibited a higher electron transporting performance $[35,36]$. In Figure $4 b$, the PCBM formed with regular method and OSM presented no obvious difference in UV absorbance. Note that the OSM based PCBM owned a slightly higher absorbance than the regular PCBM around the region of 2D perovskite characteristic peak (around 600nm) which can be observed from the inset of Figure $4 \mathrm{~b}$. It is deduced that the slightly increased absorbance may arise from a better film coverage of OSM based PCBM [37]. This result agreed with the SEM data in Figure 3, i.e., the OSM based PCBM was more compact than the generally formed PCBM. We also analyzed the EIS to study the variation of electric performance. As shown in Figure S1, the Nyquist plots with two characteristic arcs and equivalent circuit were exhibited, from which the recombination resistance $\left(R_{\text {rec }}\right)$, series resistance $\left(R_{S}\right)$, and capacitor $C$ can be observed. The OSM based sample exhibited a $R_{\mathrm{s}}$ of $27.4 \Omega$ and $R_{\mathrm{ct}}$ of $1604.7 \Omega$, while the regular sample presented a $R_{s}$ of $31.6 \Omega$ and $R_{c t}$ of $1158.5 \Omega$. The decreased $R_{s}$ and increased $R_{\text {rec }}$ indicated the improved electron transporting performance and suppressed charge recombination, respectively, probably suggesting the defect-passivated perovskite [38]. 


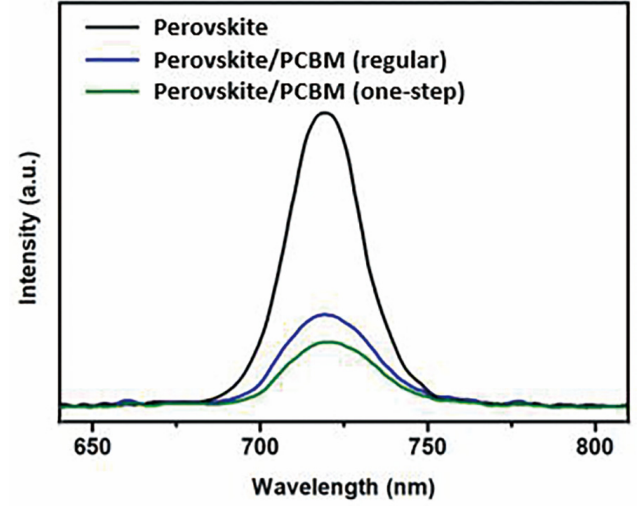

(a)

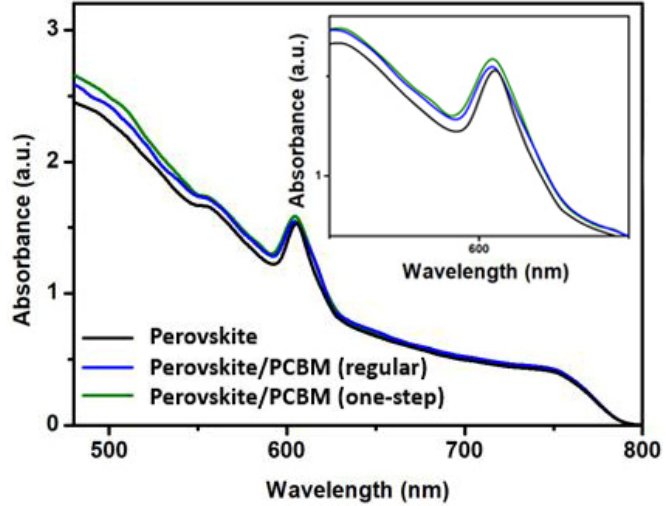

(b)

Figure 4. (a) PL spectra and (b) UV absorbance of samples with configuration of perovskite, perovskite/PCBM (regular method), and perovskite/PCBM (one-step method).

To search for the optimized PCE, we measured the J-V characteristics for OSM formed PCBM using different concentrations. To obtain the more obvious changes in data, we used $10 \mathrm{mg} \mathrm{mL}^{-1}$ increment of the concentrations. As shown in Figure $5 \mathrm{a}$, when the concentrations of PCBM solution were increased from 10 to $30 \mathrm{mg} \mathrm{mL}^{-1}$, the PCEs were elevated from $10.2 \%$ to $12.8 \%$ and then rolled back to $10.5 \%$. The excess solution concentration may lead to unsuitable film thickness, hindering the effective electron transportation.

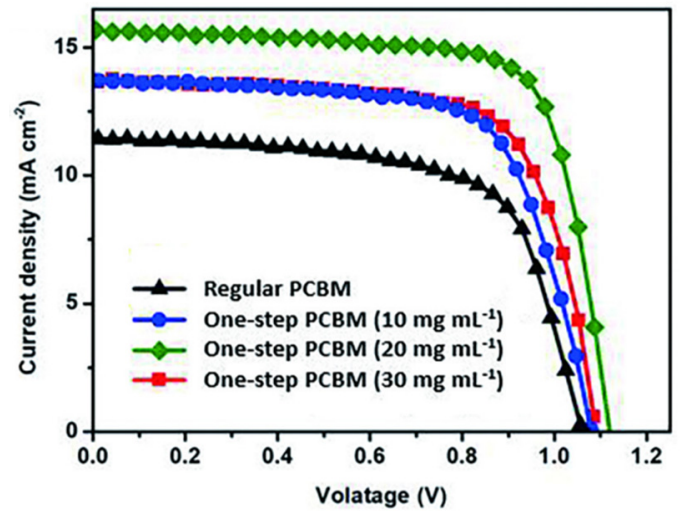

(a)

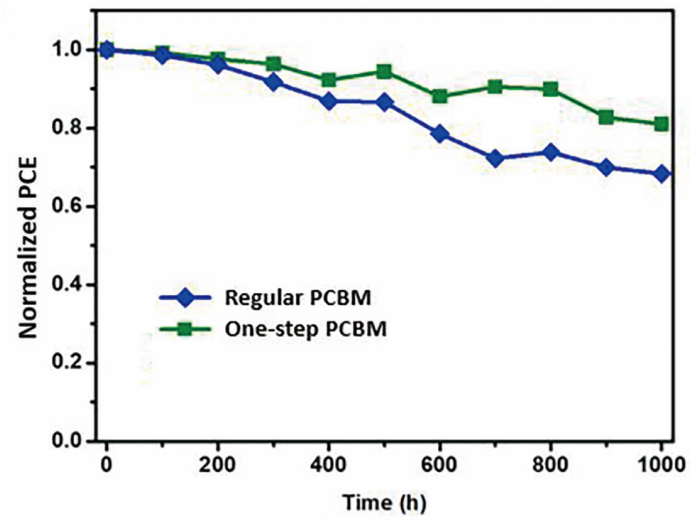

(b)

Figure 5. (a) J-V characteristics of 2D devices based on ETLs deposited under different parameters. (b) Long-term stability test for perovskite devices based on different PCBM deposition methods for $1000 \mathrm{~h}$ under illumination at around $25^{\circ} \mathrm{C}$ without encapsulation (about 30\% humidity).

In addition to improved PCE, the environmental stability of devices is also essential for the device performance. Therefore, we evaluated the long-term stability of perovskite devices based on different PCBM deposition methods for $1000 \mathrm{~h}$ under illumination at around $25{ }^{\circ} \mathrm{C}$ without encapsulation (about $30 \%$ humidity). As shown in Figure $5 \mathrm{~b}$, the experimental group exhibited a slower degradation rate, retaining about $81 \%$ of the initial PCE, while the control group maintained only about $68 \%$ of the initial PCE. This can be explained by the fact that the OSM based sample owned the defect-suppressed perovskite and quality-improved PCBM, suppressing the degradation that occurred from the defects.

\section{Conclusions}

In summary, we reported a facile method to form the perovskite/PCBM heterojunction with better quality using the OSM. The defects of perovskite film were passivated and the morphology of PCBM was improved with higher film coverage and less gaps, ensuring 
a better electron transporting performance and suppressed charge recombination. As a result, the OSM based 2D PSC delivered a PCE of $12.8 \%$ along with $V_{o c}$ of $1.12 \mathrm{~V}, J_{s c}$ of $15.69 \mathrm{~mA} \mathrm{~cm}^{-2}$, and FF of 0.73 (reverse scan). Thanks to the defect-passivated perovskite and quality-improved PCBM, the degradation rate was effectively suppressed. After storing the samples for $1000 \mathrm{~h}$ under illumination at around $25^{\circ} \mathrm{C}$ without encapsulation, the experimental group retained about $81 \%$ of the initial PCE, which is higher than that $(68 \%)$ of control group.

Supplementary Materials: The following are available online at https:/ /www.mdpi.com/article/ 10.3390/cryst11080933/s1, Figure S1: Nyquist plots of ETL fabricated in different approaches in 2D PSCs.

Author Contributions: Conceptualization, F.Z. and X.X.; methodology, C.X.; investigation, H.W.; data curation, G.L.; writing—original draft preparation, H.W.; writing—review and editing, S.W.; supervision, S.W.; project administration, F.Z.; funding acquisition, F.Z. and X.X. All authors have read and agreed to the published version of the manuscript.

Funding: This work was supported by the National Research Foundation of Korea (NRF) funded by the Ministry of Science and ICT (Grant No.: 2020R1GA1102816), and the Department of Science \& Technology of Jilin Province (Grant No.: 20160414043GH).

Institutional Review Board Statement: Not applicable.

Informed Consent Statement: Not applicable.

Data Availability Statement: Data are available on request from the authors.

Acknowledgments: We acknowledge the financial support from the National Research Foundation of Korea (NRF).

Conflicts of Interest: The authors declare no conflict of interest. We identify and declare that no personal circumstances or interest that may be perceived as inappropriately influencing the representation or interpretation of reported research results. Additionally, the funders had no role in the design of the study; in the collection, analyses, or interpretation of data; in the writing of the manuscript, or in the decision to publish the results.

\section{References}

1. Jeon, N.J.; Noh, J.H.; Yang, W.S.; Kim, Y.C.; Ryu, S.; Seo, J.; Seok, S.I. Compositional engineering of perovskite materials for high-performance solar cells. Nature 2015, 517, 476-480. [CrossRef]

2. Liu, M.; Johnston, M.B.; Snaith, H.J. Efficient planar heterojunction perovskite solar cells by vapour deposition. Nature 2013, 501, 395-398. [CrossRef]

3. Jeon, N.J.; Noh, J.H.; Kim, Y.C.; Yang, W.S.; Ryu, S.; Seok, S.I. Solvent engineering for high-performance inorganic-organic hybrid perovskite solar cells. Nat. Mater. 2014, 13, 897-903. [CrossRef]

4. Yang, W.S.; Noh, J.H.; Jeon, N.J; Kim, Y.C.; Ryu, S.; Seo, J.; Seok, S.I. High-performance photovoltaic perovskite layers fabricated through intramolecular exchange. Science 2015, 348, 1234-1237. [CrossRef] [PubMed]

5. Yang, W.S.; Park, B.-W.; Jung, E.H.; Jeon, N.J.; Kim, Y.C.; Lee, D.U.; Shin, S.S.; Seo, J.; Kim, E.K.; Noh, J.H.; et al. Iodide management in formamidinium-lead-halide-based perovskite layers for efficient solar cells. Science 2017, 356, 1376-1379. [CrossRef] [PubMed]

6. Cheng, X.; Yang, S.; Cao, B.; Tao, X.; Chen, Z. Single crystal perovskite solar cells: Development and perspectives. Adv. Funct. Mater. 2019, 30, 1905021. [CrossRef]

7. Huang, F.; Siffalovic, P.; Li, B.; Yang, S.; Zhang, L.; Nadazdy, P.; Cao, G.; Tian, J. Controlled crystallinity and morphologies of 2D Ruddlesden-Popper perovskite films grown without anti-solvent for solar cells. Chem. Eng. J. 2020, 394, 124959. [CrossRef]

8. Lee, J.; Kim, J.; Lee, C.-L.; Kim, G.; Kim, T.K.; Back, H.; Jung, S.; Yu, K.; Hong, S.; Lee, S.; et al. A printable organic electron transport layer for low-temperature-processed, hysteresis-free, and stable planar perovskite solar cells. Adv. Energy Mater. 2017, 7, 1700226. [CrossRef]

9. Wang, T.; Scarratt, N.W.; Yi, H.; Dunbar, A.; Pearson, A.; Watters, D.C.; Glen, T.; Brook, A.C.; Kingsley, J.; Buckley, A.R.; et al. Fabricating high performance, donor-acceptor copolymer solar cells by spray-coating in air. Adv. Energy Mater. 2013, 3, 505-512. [CrossRef]

10. Deng, Y.; Peng, E.; Shao, Y.; Xiao, Z.; Dong, Q.; Huang, J. Scalable fabrication of efficient organolead trihalide perovskite solar cells with doctor-bladed active layers. Energy Environ. Sci. 2015, 8, 1544-1550. [CrossRef]

11. Bishop, J.E.; Routledge, T.J.; Lidzey, D.G. Advances in spray-cast perovskite solar cells. J. Phys. Chem. Lett. 2018, 9, 1977-1984. [CrossRef] 
12. Huang, H.; Shi, J.; Zhu, L.; Li, D.; Luo, Y.; Meng, Q. Two-step ultrasonic spray deposition of CH3NH3PbI3 for efficient and large-area perovskite solar cell. Nano Energy 2016, 27, 352-358. [CrossRef]

13. Ono, L.K.; Juarez-Perez, E.J.; Qi, Y. Progress on perovskite materials and solar cells with mixed cations and halide anions. ACS Appl. Mater. Interfaces 2017, 9, 30197-30246. [CrossRef]

14. Zhang, M.; Yun, J.S.; Ma, Q.; Zheng, J.; Lau, C.F.J.; Deng, X.; Kim, J.; Kim, D.; Seidel, J.; Green, M.A.; et al. High-efficiency rubidium-incorporated perovskite solar cells by gas quenching. ACS Energy Lett. 2017, 2, 438-444. [CrossRef]

15. Jacobs, R.; Luo, G.; Morgan, D. Materials discovery of stable and nontoxic halide perovskite materials for high-efficiency solar cells. Adv. Funct. Mater. 2019, 29, 1804354. [CrossRef]

16. Grandhi, G.; Matuhina, A.; Liu, M.; Annurakshita, S.; Ali-Löytty, H.; Bautista, G.; Vivo, P. Lead-free cesium titanium bromide double perovskite nanocrystals. Nanomaterials 2021, 11, 1458. [CrossRef]

17. Li, X.; Zeng, P.; Ou, Q.; Zhang, S. Fabrication of perovskite film-coated hollow capillary fibers using a fast solvent exchange method. Nanomaterials 2021, 11, 1483. [CrossRef]

18. Xu, C.; Liu, Z.; Lee, E.-C. High-performance metal oxide-free inverted perovskite solar cells using poly (bis (4-phenyl)(2, 4, 6-trimethylphenyl) amine) as the hole transport layer. J. Mater. Chem. C 2018, 6, 6975-6981. [CrossRef]

19. Xu, C.; Liu, Z.; Lee, E.-C. High-performance inverted planar perovskite solar cells using a pristine fullerene mixture as an electron-transport layer. J. Mater. Chem. C 2019, 7, 6956-6963. [CrossRef]

20. Xu, C.; Liu, Z.; Lee, E.-C. Crystallization management for high-performance perovskite solar cells by introducing antisolvent into perovskite precursor. J. Mater. Chem. C 2020, 8, 15860-15867. [CrossRef]

21. Xu, C.; Liu, Z.; Lee, E.-C. Non-equivalent Tl doping for high performance perovskite solar cells: Crystal quality improvement with enhanced p-type character. J. Power Sources 2020, 479, 228818. [CrossRef]

22. Zhang, F.; Lu, H.; Tong, J.; Berry, J.J.; Beard, M.C.; Zhu, K. Advances in two-dimensional organic-inorganic hybrid perovskites Energy Environ. Sci. 2020, 13, 1154-1186. [CrossRef]

23. Zhang, X.; Ren, X.; Liu, B.; Munir, R.; Zhu, X.; Yang, D.; Li, J.; Liu, Y.; Smilgies, D.-M.; Li, R.; et al. Stable high efficiency two-dimensional perovskite solar cells via cesium doping. Energy Environ. Sci. 2017, 10, 2095-2102. [CrossRef]

24. Zhu, X.; Xu, Z.; Zuo, S.; Feng, J.; Wang, Z.; Zhang, X.; Zhao, K.; Zhang, J.; Liu, H.; Priya, S.; et al. Vapor-fumigation for record efficiency two-dimensional perovskite solar cells with superior stability. Energy Environ. Sci. 2018, 11, 3349-3357. [CrossRef]

25. Cao, D.H.; Stoumpos, C.; Farha, O.K.; Hupp, J.T.; Kanatzidis, M.G. 2D homologous perovskites as light-absorbing materials for solar cell applications. J. Am. Chem. Soc. 2015, 137, 7843-7850. [CrossRef]

26. Zhou, N.; Shen, Y.; Li, L.; Tan, S.; Liu, N.; Zheng, G.; Chen, Q.; Zhou, H. Exploration of crystallization kinetics in quasi two-dimensional perovskite and high performance solar cells. J. Am. Chem. Soc. 2018, 140, 459-465. [CrossRef]

27. Etgar, L. The merit of perovskite's dimensionality; can this replace the 3D halide perovskite? Energy Environ. Sci. 2018, 11, 234-242. [CrossRef]

28. Chen, Y.; Yu, S.; Sun, Y.; Liang, Z. Phase engineering in quasi-2D ruddlesden-popper perovskites. J. Phys. Chem. Lett. 2018, 9, 2627-2631. [CrossRef]

29. Tsai, H.; Nie, W.; Blancon, J.-C.; Stoumpos, C.; Asadpour, R.; Harutyunyan, B.; Neukirch, A.J.; Verduzco, R.; Crochet, J.; Tretiak, S.; et al. High-efficiency two-dimensional Ruddlesden-Popper perovskite solar cells. Nature 2016, 536, 312-316. [CrossRef]

30. Ren, H.; Yu, S.; Chao, L.; Xia, Y.; Sun, Y.; Zuo, S.; Li, F.; Niu, T.; Yang, Y.; Ju, H.; et al. Efficient and stable Ruddlesden-Popper perovskite solar cell with tailored interlayer molecular interaction. Nat. Photon. 2020, 14, 154-163. [CrossRef]

31. Zhang, X.; Wu, G.; Fu, W.; Qin, M.; Yang, W.; Yan, J.; Zhang, Z.; Lu, X.; Chen, H. Orientation regulation of Phenylethylammonium cation based 2D perovskite solar cell with efficiency higher than 11\%. Adv. Energy Mater. 2018, 8, 1702498. [CrossRef]

32. Zhou, L.; Chang, J.; Liu, Z.; Sun, X.; Lin, Z.; Chen, D.; Zhang, C.; Zhang, J.; Hao, Y. Enhanced planar perovskite solar cell efficiency and stability using a perovskite/PCBM heterojunction formed in one step. Nanoscale 2018, 10, 3053-3059. [CrossRef]

33. Shao, Y.; Yuan, Y.; Huang, J. Correlation of energy disorder and open-circuit voltage in hybrid perovskite solar cells. Nat. Energy 2016, 1, 15001. [CrossRef]

34. Wolff, C.M.; Zu, F.; Paulke, A.; Toro, L.P.; Koch, N.; Neher, D. Reduced interface-mediated recombination for high open-circuit voltages in $\mathrm{CH}_{3} \mathrm{NH}_{3} \mathrm{PbI}_{3}$ solar cells. Adv. Mater. 2017, 29, 1700159. [CrossRef] [PubMed]

35. Liang, P.-W.; Chueh, C.-C.; Williams, S.T.; Jen, A.K.-Y. Roles of fullerene-based interlayers in enhancing the performance of organometal perovskite thin-film solar cells. Adv. Energy Mater. 2015, 5, 1402321. [CrossRef]

36. Chang, C.-Y.; Huang, W.-K.; Chang, Y.-C.; Lee, K.-T.; Chen, C.-T. A solution-processed n-doped fullerene cathode interfacial layer for efficient and stable large-area perovskite solar cells. J. Mater. Chem. A 2016, 4, 640-648. [CrossRef]

37. Cui, C.; Li, Y.; Li, Y. Fullerene derivatives for the applications as acceptor and cathode buffer layer materials for organic and perovskite solar cells. Adv. Energy Mater. 2017, 7, 1601251. [CrossRef]

38. Xia, F.; Wu, Q.; Zhou, P.; Li, Y.; Chen, X.; Liu, Q.; Zhu, J.; Dai, S.; Lu, Y.; Yang, S. efficiency enhancement of inverted structure perovskite solar cells via oleamide doping of PCBM electron transport layer. ACS Appl. Mater. Interfaces 2015, 7, 13659-13665. [CrossRef] [PubMed] 